\title{
Matrix Metalloproteinases and Other Matrix Proteinases in Relation to Cariology: The Era of 'Dentin Degradomics'
}

\author{
Leo Tjäderhane ${ }^{a, b}$ Marília Afonso Rabelo Buzalaf ${ }^{c}$ Marcela Carrilho ${ }^{d}$ \\ Catherine Chaussain ${ }^{e, f}$ \\ anstitute of Dentistry, University of Oulu, and ${ }^{b}$ Medical Research Center Oulu, Oulu University Hospital and University of \\ Oulu, Oulu, Finland; ' Department of Biological Sciences, Bauru School of Dentistry, University of São Paulo, Bauru, and \\ ${ }^{\mathrm{d} B i o m a t e r i a l s ~ R e s e a r c h ~ G r o u p ~ a n d ~ B i o t e c h n o l o g y ~ a n d ~ I n n o v a t i o n ~ i n ~ H e a l t h, ~ U N I A N-S P, ~ S a ̃ o ~ P a u l o, ~ B r a z i l ; ~}{ }^{e}$ EA 2496 Dental \\ School, University Paris Descartes, and f Odontology Department, Bretonneau Hospital, AP-HP, Paris, France
}

\section{Key Words}

Caries · Cathepsin · Collagen · Dentin · Enzyme · Erosion ·

Hybrid layer $\cdot$ Matrix metalloproteinase

\begin{abstract}
Dentin organic matrix, with type I collagen as the main component, is exposed after demineralization in dentinal caries, erosion or acidic conditioning during adhesive composite restorative treatment. This exposed matrix is prone to slow hydrolytic degradation by host collagenolytic enzymes, matrix metalloproteinases (MMPs) and cysteine cathepsins. Here we review the recent findings demonstrating that inhibition of salivary or dentin endogenous collagenolytic enzymes may provide preventive means against progression of caries or erosion, just as they have been shown to retain the integrity and improve the longevity of resin composite filling bonding to dentin. This paper also presents the case that the organic matrix in caries-affected dentin may not be preserved as intact as previously considered. In partially demineralized dentin, MMPs and cysteine cathepsins with the ability to cleave off the terminal non-helical ends of collagen molecules (telopeptides) may lead to the gradual loss of intramolecular gap areas. This would seriously compromise the matrix ability for intrafibrillar remineralization, which is
\end{abstract}

considered essential in restoring the dentin's mechanical properties. More detailed data of the enzymes responsible and their detailed function in dentin-destructive conditions may not only help to find new and better preventive means, but better preservation of demineralized dentin collagenous matrix may also facilitate true biological remineralization for the better restoration of tooth structural and mechanical integrity and mechanical properties.

(c) 2015 S. Karger AG, Basel

Dentinal caries, erosion and creation of the hybrid layer for the bonding of composite restorations all have two things in common. In all of them dentin is demineralized, revealing the collagenous organic matrix, and the degradation of this matrix is believed to be detrimental to the tissue if not properly protected. The majority of research in all these conditions has focused on demineralization. In caries and erosion, demineralization has been almost held as a synonym for disease progression and severity. In adhesive dentistry, partial or complete demineralization is a prerequisite for successful bonding with contemporary adhesives. Infiltration of dentin collagen with adhesive monomers creates the collagen-adhesive hybrid layer responsible for the composite-dentin bond. The role

\section{KARGER 125\%}

(c) 2015 S. Karger AG, Base

0008-6568/15/0493-0193\$39.50/0

E-Mail karger@karger.com

www.karger.com/cre
Leo Tjäderhane

Institute of Dentistry, University of Oulu

PO Box 5281

FI-90014 Oulu (Finland)

E-Mail leo.tjaderhane@oulu.fi 
of enzymatic loss of collagen component of the hybrid layer by dentinal enzymes, at least partially responsible for the time-related loss of bond strength, has been recognized and is under active research [Tjäderhane et al., 2013a, b]. Recently the role of the dentinal matrix also in caries and erosion has gained more attention both in the pathological processes and as a means to improve preventive measures.

Degradomics is an application of genomic and proteomic approaches to identify the protease and protease substrate repertoires [López-Otín and Overall, 2002] both in physiological and pathological conditions. The determination of protease activity in clinical specimens can offer therapeutic options in different diseases [Findeisen and Neumaier, 2012]. 'Dentin degradomics' refers to the field of research aiming to identify the enzymes and their specific roles, substrates and end products in dentinpulp complex physiology and pathologies. The aim of this paper, based on presentations given at the European Organisation for Caries Research (ORCA) Saturday Afternoon Symposium in Liverpool, UK in July 2013, is (1) to provide an overview of the current knowledge of the dentin matrix role and fate in dentin pathologies, and (2) to discuss how the dentin degradomic approach could help to understand and manage these conditions.

\section{Dentin and Dentinal Proteolytic Enzymes}

Dentin is composed of approximately 70 weight percent/50 volume percent minerals (biological hydroxyapatite) and the organic matrix (about 20 weight percent/30 volume percent), the remaining fraction being water. Structurally, dentin can be described as a nanocrystalline reinforced composite, while enamel would be a dense ceramic with impurities [Tjäderhane et al., 2012]. About $90 \%$ of the dentin organic matrix is collagen, consisting almost exclusively of type I collagen. The remaining $10 \%$ of dentin organic matrix consists of non-collagenous proteins (NCPs) and lipids $(<2 \%)$. NCPs are a heterogeneous group of proteoglycans, phosphoproteins, glycoproteins, serum proteins, enzymes and growth factors. While several members of the NCPs may have significant impact on dentin-pulp complex physiology and pathologies (for example, the role of growth factors liberated from dentin affecting the reactionary or reparative dentinogenesis), with the exception of the enzymes and some of their substrates in mineralized dentin, their functions are mainly beyond the focus of this article. For detailed overviews, the readers are referred to the recent review articles [Maz- zoni et al., 2012a; Orsini et al., 2012; Tjäderhane and Haapasalo, 2012; Chaussain et al., 2013].

Since dentin is the most abundant mineralized tissue in tooth, its mechanical performance is considered to have major significance to the overall function of teeth [Bertassoni et al., 2009]. Dentin collagen is mineralized in mineralization front after the organization of collagenous matrix in predentin [Tjäderhane and Haapasalo, 2012]. Proteoglycans are believed to concentrate in the collagen gap zone, with the protein core surrounding the collagen fibril, and glycosaminoglycan chains penetrating inside the fibrils. Inside, calcium ions related to the glycosaminoglycan chains would start the crystal nucleation [Dechichi et al., 2007]. Extrafibrillar mineralization in the spaces separating the collagen fibrils follows the intrafibrillar mineralization. Intrafibrillar mineral has the major role in dentin mechanical properties [Kinney et al., 2003; Balooch et al., 2008; Bertassoni et al., 2009, 2011]. Dentinogenesis imperfecta type II (DI-II) dentin lacks intrafibrillar mineral, with approximately $33 \%$ less mineral than normal dentin [Kinney et al., 2001, 2003]. However, the relative reductions in elastic modulus (74\%) and hardness (76\%) of DI-II dentin compared to normal dentin indicate the importance of intrafibrillar mineral, which stiffens the collagen fibrils, to the dentin mechanical (elastic) behavior under load [Kinney et al., 2003].

\section{Dentinal Enzymes Involved in Dentin Matrix \\ Degradation}

Matrix metalloproteinases (MMPs) are a family of $\mathrm{Zn}^{2+}$ - and $\mathrm{Ca}^{2+}$-dependent enzymes, which are important in many biological and pathological processes because collectively they are able to degrade practically all extracellular matrix components. In humans, the 23 members of the MMP family are frequently divided into six groups collagenases, gelatinases, stromelysins, matrilysins, membrane-type MMPs and other MMPs - based on substrate specificity and homology. Even though this classification is practical, it underestimates the complexity of MMP functions and biological activities, as most MMPs can - at least in vitro - degrade several substrates with variable specificities. For example, collagenase- 1 and collagenase-3 (MMP-1 and MMP-13) also degrade gelatin at a slow rate, and gelatinases MMP-2 and MMP-9 degrade several types of collagen with telopeptidase activity against type I collagen. Therefore, more recently MMPs have often been classified according to their molecular structure [Mazzoni et al., 2012a; Tjäderhane et al., 2013a]. MMPs are synthesized and mostly secreted as inactive proenzymes (zymogens), in which the prodomain pre- 


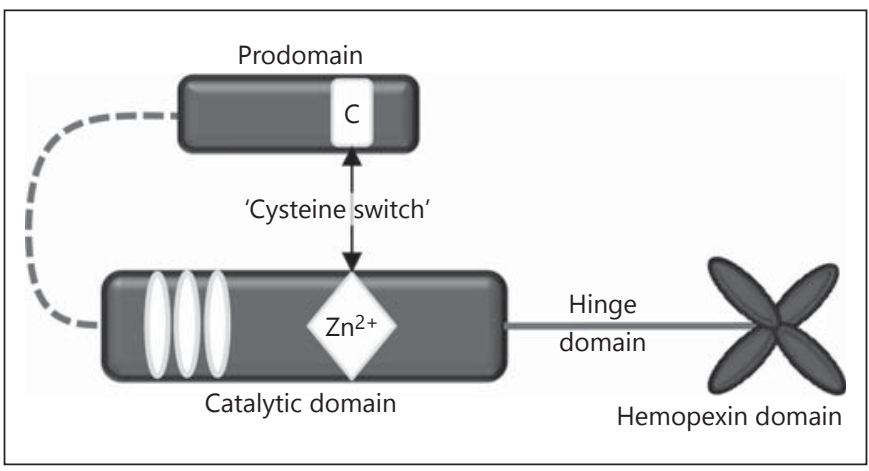

Fig. 1. General structure of MMPs. The cysteine residue (C) of the MMP prodomain co-ordinates with the catalytic domain $\mathrm{Zn}^{2+}$ ion, forming a so-called 'cysteine switch' and hiding the functional site of the enzyme. When the prodomain is removed, the catalytic site is exposed and the enzyme is activated. The hemopexin domain 'propeller' is present in most MMPs and attached to the catalytic domain by a flexible hinge domain. The hemopexin domain contributes to substrate recognition, enzyme activation and protease localization. The ovals within the catalytic domain represent fibronectin type II repeats present in gelatinases MMP-2 and MMP-9. They are responsible for the gelatin substrate recognition and binding, providing high affinity of gelatinases against gelatin.

vents the functional activity of the catalytic domain. Activation occurs when the prodomain bridge with the catalytic zinc (the so-called 'cysteine switch') is disrupted by prodomain cleavage by other MMPs, cysteine cathepsins or other proteinases, or chemically, e.g. by $\mathrm{pH}$ changes (fig. 1).

There are 11 human cysteine cathepsins, the cathepsins $\mathrm{B}, \mathrm{C}, \mathrm{F}, \mathrm{H}, \mathrm{K}, \mathrm{L}, \mathrm{O}, \mathrm{S}, \mathrm{V}, \mathrm{X}$ and $\mathrm{W}$. The majority of cathepsins are ubiquitously expressed in human tissues, but cathepsins $\mathrm{K}, \mathrm{W}$ and $\mathrm{S}$ show more restricted cell- or tissue-specific distribution. Cysteine cathepsins participate intracellularly in diverse processes, such as normal protein turnover, pro-protein processing and apoptosis. Extracellularly, they can contribute directly to the degradation of the extracellular matrix, and participate in proteolytic cascades that amplify the degradative capacity. Unlike MMPs, which have the optimum functional activity in a neutral environment, cysteine cathepsins have optimal activity in a slightly acidic $\mathrm{pH}$, generally between 5 and 6. However, $\mathrm{pH}$ optimum may depend on the substrate: for example, cathepsin $\mathrm{K}$ degrades collagen most efficiently at a $\mathrm{pH}$ between 5 and 6 , but gelatin still at a neutral $\mathrm{pH}$. Cathepsin $\mathrm{B}$ endopeptidase activity has a $\mathrm{pH}$ optimum around 7.4. Cysteine cathepsins are usually considered to be unstable or denatured in neutral and alkaline $\mathrm{pH}$, but this may also be condition-dependent: for example, cathepsin $\mathrm{K}$ stability in neutral $\mathrm{pH}$ is greatly in-

MMPs and Other Matrix Proteinases in Relation to Cariology creased by chondroitin-4-sulphate [Dickinson, 2002; Mazzoni et al., 2012a; Turk et al., 2012; Tjäderhane et al., 2013a].

Cathepsin $\mathrm{K}$ is the major protease responsible for bone resorption and remodeling, and cathepsin $\mathrm{K}$ can degrade collagen at various sites inside the molecule's helical region. This property is similar to bacterial collagenases and unique among mammalian proteinases, as all collagenolytic MMPs cleave the collagen molecule helical part at one distinct site. Several cathepsins can degrade gelatin, and at least cathepsins $\mathrm{K}, \mathrm{B}$ and $\mathrm{L}$ cleave collagen in the non-helical telopeptide extensions. In tissues, glycosaminoglycans form complexes with cathepsin and may affect their function in a highly complex manner [Mazzoni et al., 2012a; Turk et al., 2012; Tjäderhane et al., 2013a].

To date, intact human dentin matrix has been shown to contain MMP-8 (collagenase 2) [Sulkala et al., 2007], MMP-2 and MMP-9 (gelatinases) [Martin-De Las Heras et al., 2000; Mazzoni et al., 2007; Boushell et al., 2008; Mazzoni et al., 2009; Santos et al., 2009; Vidal et al., 2014], MMP-3 (stromelysin-1) [Boukpessi et al., 2008; Mazzoni et al., 2011], MMP-20 [Shimada et al., 2009], cysteine cathepsin B [Tersariol et al., 2010; Vidal et al., 2014] and cysteine cathepsin K [Vidal et al., 2014]. In addition to abundant gelatinolytic enzymes in dentinal tubules [Mazzoni et al., 2012b; Pessoa et al., 2013], at least MMP-20 is present in dentinal fluid [Sulkala et al., 2002]. Tissue inhibitors of metalloproteinases TIMP-1 and TIMP-2 and MMP inhibitors $\alpha 2$-macroglobulin and fetuin-A are also present in marked quantities in dentin [Mazzoni et al., 2012a; Tjäderhane et al., 2013a].

The physiological roles of collagenolytic enzymes in dentin are not well known. They may participate e.g. in peritubular and tertiary dentin formation, and in the release of dentinal growth factors which in turn would regulate defensive reactions in the pulp [Tjäderhane et al., 2002; Hannas et al., 2007; Charadram et al., 2012; Mazzoni et al., 2012a; Muromachi et al., 2012; Chaussain et al., 2013; Tjäderhane et al., 2013a]. They are, however, capable and sufficient to degrade demineralized dentin in vitro [Carrilho et al., 2009; Tezvergil-Mutluay et al., 2010, 2013; Toledano et al., 2013].

\section{Host Proteases in Caries}

Already in 1983, Dayan et al. [1983] demonstrated that intact, but especially carious human dentin had collagenolytic activity against synthetic peptide. This finding was mostly ignored, possibly because carious dentin was be- 


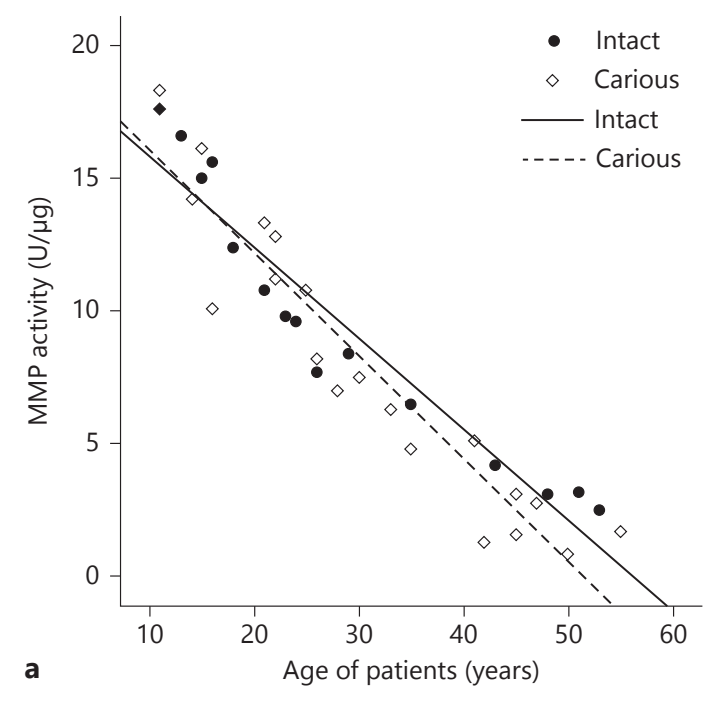

Fig. 2. Correlation between the age of patients and MMP (a) and cathepsin (b) activities in carious and intact dentin. The original values of intact dentin were multiplied by 10 to fit the curves into same graphs with carious dentin. For both MMP and cathepsin activities, the correlations between age and activities are highly sig-

lieved to contain bacterial collagenases, and because the knowledge of MMPs was still very limited. Only 15 years later, mature human odontoblasts were shown to express MMP-2 and MMP-9 [Tjäderhane et al., 1998b], MMP-2, MMP-9 and MMP-8 were identified in carious dentin, and the role of MMPs in the degradation of dentin collagen was demonstrated [Tjäderhane et al., 1998a]. At the same time, the activation of latent salivary pro-MMPs by exposure to low $\mathrm{pH}$ followed by neutralization (so-called acid activation) was also shown [Tjäderhane et al., 1998a; Sulkala et al., 2001]. The same phenomenon was later demonstrated with dentinal MMPs [Mazzoni et al., 2006; Nishitani et al., 2006]. The acid activation occurs in $\mathrm{pH}$ changes relevant to caries, indicating the role of bacterial acids in the process.

Other studies have confirmed the presence of these MMPs in caries-affected dentin [van Strijp et al., 2003; Boushell et al., 2008; Shimada et al., 2009; Toledano et al., 2010; Charadram et al., 2012]. The cysteine cathepsins were also identified in carious dentin [Nascimento et al., 2011; Vidal et al., 2014]. Recent studies have also indicated MMPs among susceptibility genes for dental caries [Tannure et al., 2012a, b; Wang et al., 2013].

Based on current knowledge, it is not possible to determine with certainty the exact role and importance of salivary, dentinal or pulp-derived (via dentinal fluid) en-

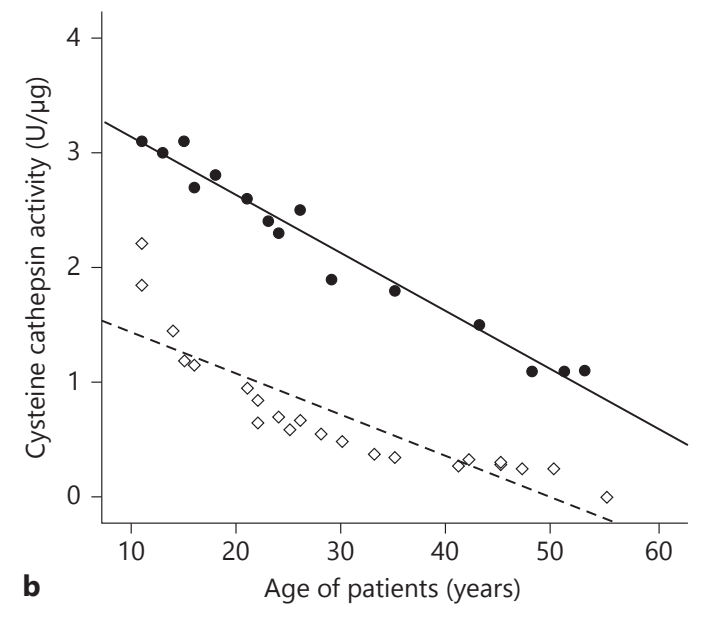

nificant ( $\mathrm{p}<0.001$ in all cases; Pearson correlation test), and the activities in carious dentin are significantly higher $(\mathrm{p}<0.01$ for cathepsins and $\mathrm{p}<0.001$ for MMPs, $t$ test). Data adapted from Tersariol et al. [2010] and Nascimento et al. [2011].

zymes in dentinal caries lesions. Saliva contains several MMPs, which have been experimentally shown to efficiently degrade exposed dentinal collagen matrix [Tjäderhane et al., 1998a]. MMP-9 is perhaps the most abundant salivary MMP and predominant in dentin caries lesions [Tjäderhane et al., 1998a]. High relative presence of MMP-8 and MMP-9 in outer caries layer compared to inner (caries-affected) layer [Shimada et al., 2009] indicates saliva as a source of these enzymes, supported by the strong correlation of salivary MMP-8 with caries [Hedenbjörk-Lager et al., 2015]. Saliva also contains cysteine cathepsins [Nascimento et al., 2011], at least cathepsin B [van Strijp et al., 2003]. Interestingly, significantly higher levels of the cathepsin inhibitors cystatin and lipocalin-1 were found in saliva and pellicle of caries-free subjects than those with high DMFT [Vitorino et al., 2006].

Decreasing intensity in MMP-2 staining from the pulp towards the enamel [Niu et al., 2011] and decreasing detection and activities of collagenolytic enzymes with age [Martin-de Las Heras et al., 2000; Tersariol et al., 2010] have raised the question of the true importance of these enzymes in caries. It has to be emphasized that even though this negative correlation can be seen in both intact and carious dentin, the activities are markedly (3- to 11fold) higher in carious tissue (fig. 2), which may indicate the role of dentinal fluid as a source of the enzymes. This 
is supported by a recent finding with intensively increased detection of cathepsin K and cathepsin B as well as MMP2 and MMP-9 in caries-affected dentin close to the dentin-pulp border [Vidal et al., 2014]. Extremely intense gelatinolytic activity in mantle dentin [Pessoa et al., 2013] presumably due to MMP-2 [Boushell et al., 2008; Toledano et al., 2010; Boushell et al., 2011; Niu et al., 2011] may indicate that MMP-2 is involved at least in the early lateral spreading of caries under the dentin-enamel junction [Hietala et al., 1993; Tjäderhane et al., 1995]. Intensive gelatinolytic activity has been observed in dentinal tubules [Mazzoni et al., 2012b; Pessoa et al., 2013]. In addition, TGF- $\beta$ (indicated to regulate dentin-pulp complex response to caries [Cooper et al., 2011; Charadram et al., 2012] and identified as a caries susceptibility gene [Wang et al., 2013]) increases MMP-9 synthesis in mature human odontoblasts in vitro [Tjäderhane et al., 1998b], and MMP-2 [Boushell et al., 2011], MMP-9 [Zehnder et al., 2011] and MMP-20 [Sulkala et al., 2002] increase in dentinal tubules of carious teeth. MMP-2 and TIMP-2 expressions are also significantly up-regulated in odontoblasts under the carious lesion [Charadram et al., 2012]. The granular appearance of gelatinases close to the dentin-pulp border but not in the vicinity of the dentinenamel junction [Pessoa et al., 2013] may indicate that MMPs are packed into granules or matrix vesicles for transportation in tubules. Matrix vesicles, known to be important in biomineralization, contain MMP-2, MMP3 and MMP-13 [Golub, 2009]. And finally, a significant increase in the cathepsin activity with increasing lesion depth [Nascimento et al., 2011] may be caused by the influx of odontoblast- or pulp-derived enzymes via dentinal tubules. Dentinal fluid as a continuous source of collagenolytic enzymes indicates that age- or dentin depthrelated differences in the presence of enzyme in intertubular matrix [Tersariol et al., 2010; Niu et al., 2011] may not be that significant in respect to the caries process.

There are numerous natural and synthetic MMP inhibitors that have been examined or proposed to be useful to eliminate or reduce dentin matrix degradation [Tjäderhane et al., 2013b]. Tetracycline and its derivates have long been known to inhibit MMPs, and they have been extensively studied especially in the treatment of periodontitis [Sorsa et al., 2006; Hannas et al., 2007]. Animal experiments have indicated that MMP inhibition by intraoral administration of chemical MMP inhibitors could reduce caries progression in dentin [Tjäderhane et al., 1999; Sulkala et al., 2001]. Chemically modified tetracycline-3 (CMT-3) (tetracycline analogue without antimicrobial effect [Sorsa et al., 2006]) can reduce the progres-

MMPs and Other Matrix Proteinases in Relation to Cariology sion of rat molar dentinal caries by $60-87 \%$ [Tjäderhane et al., 1999; Sulkala et al., 2001]. Zoledronate (a bisphosphonate with MMP-inhibiting activity) was equally effective [Sulkala et al., 2001], while with CMT-5 (another tetracycline analogue lacking most of the MMP-inhibitory effect of CMT-3) the effect was markedly lower or absent [Tjäderhane et al., 1999; Sulkala et al., 2001]. CMT-3 was also shown to effectively eliminate human salivary gelatinase activity [Sulkala et al., 2001], and systemic doxycycline medication has a similar effect on salivary collagenase activity [Lauhio et al., 1995]. Several synthetic MMP inhibitors are based on their zinc/calcium-chelating groups, since MMPs require metal ions for their catalytic activity [Gendron et al., 1999]. For example, ethylenediaminetetraacetic acid (EDTA) inhibits dentin endogenous MMPs [Thompson et al., 2012]. Potent MMP-inhibiting activity of chlorhexidine (CHX) involves a calcium-chelating mechanism [Gendron et al., 1999], even if inhibition of cysteine cathepsins may depend on molecular docking to the enzyme active site [Scaffa et al., 2012].

Experimental data demonstrating the reduction of dentin collagen matrix degradation with different MMP inhibitors are overwhelming [for reviews, see Tjäderhane et al., 2013a, b]. However, practically all of these experiments have used simple dentin demineralization protocols with sound dentin. As discussed below in detail, natural caries lesions develop over extended time with numerous $\mathrm{pH}$ changes, de- and remineralization cycles and slowly progressing loss of minerals. The changes caused by enzymatic activities in the dentin organic matrix may be slow and gradual. There is an urgent need for experimental in vitro models that would mimic natural progression of dentinal lesions, including the time factor, to study the effect of collagenolytic enzymes and their inhibition in caries.

\section{Fate of Dentin Collagen during Caries}

Demineralization - Role of Host Enzymes

During initial demineralization the extrafibrillar mineral is more rapidly dissolved [Balooch et al., 2008], and remaining intrafibrillar mineral crystallites should act as nucleation sites for remineralization [Bertassoni et al., 2011]. However, experimental studies with rapid de-remineralization cycles do not allow potential time-related changes in the dentin organic matrix that might occur in natural lesions. As pointed out by Ito et al. [2005], dentinal carious lesions develop over months and even years, after thousands of episodes of demineralization, neutralization and remineralization. Quantitative characterizations have shown that carious lesions are far from identi- 
Fig. 3. Analysis of dentin organic matrix components in sound and carious dentin. a Comparison of type I collagen and glycosaminoglycan side chains of proteoglycans in sound and caries-affected dentin using monoclonal antibodies and immunogold labeling. * Significantly different from sound dentin $(\mathrm{p}<0.05)$. Data from Suppa et al. [2006]. b Correlation between collagen periodicity and mineral content in sound, caries-affected and caries-infected dentin. The correlation is highly significant ( $p<0.001$, Pearson correlation test). Data adapted from Deyhle et al. [2011]. c, d Collagen periodicity values (c) and mineral content (d) in sound, caries-affected and caries-infected dentin. ${ }^{* *} \mathrm{p}<$ $0.01 ; * * * \mathrm{p}<0.001$. Data adapted from Deyhle et al. [2011]. SAXS = Small-angle $\mathrm{X}$-ray scattering.

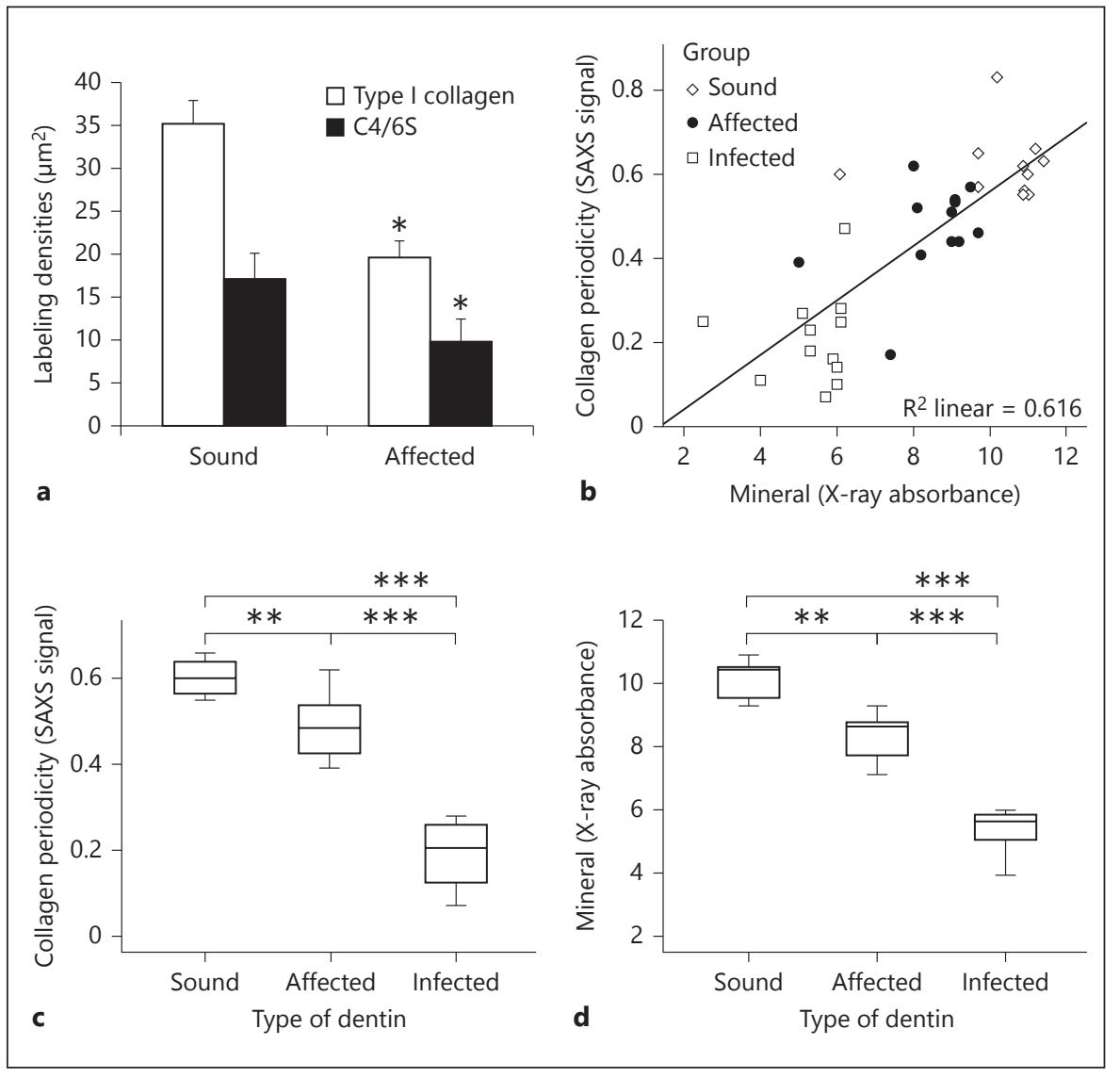

cal [Marshall et al., 2001; Ito et al., 2005]. Attempts to create 'natural' caries lesions with caries-infected and -affected dentin by demineralizing normal dentin in vitro have not been very successful.

There is a convincing amount of evidence that the recovery of dentin mechanical properties depends not only on total mineral reformed, but also on the mineral location and interaction with the matrix. In DI-II dentin the absence of intrafibrillar mineral (approximately 33\% of total mineral) reduces elastic modulus and hardness by about 75\% [Kinney et al., 2003]. Attempts to remineralize demineralized dentin should thus provide for crystallization in the gap zones [Balooch et al., 2008; Bertassoni et al., 2011]. Even though direct comparison cannot be done, it is interesting to note that caries-affected (sclerotic) dentin has similar relative reduction in stiffness (79\%) and increase in shrinkage after drying (76\%) compared to normal dentin [Ito et al., 2005].

Dentin collagen matrix in caries-affected dentin has usually been considered to remain mostly intact, retaining its ability to remineralize even when up to half of the mineral content has been lost. However, this assumption has been largely based on limited data with descriptive findings, such as transmission electron microscopy demonstration of occasional banded collagen fibrils in cariesaffected dentin [Ohgushi and Fusayama, 1975] or combined scanning electron microscopy and microradiographic analysis [Arends et al., 1989]. The analyses of collagen-associated amino acids and cross-links between caries-infected, caries-affected and normal dentin have provided conflicting results [Kuboki et al., 1977; Nakornchai et al., 2004].

Contrary to earlier findings, Suppa et al. [2006] demonstrated significantly reduced detection of intact type I collagen and proteoglycans in caries-affected compared to normal dentin (fig. 3a). The authors raise concern whether the intrafibrillar remineralization of caries-affected dentin would be possible. More recently, Deyhle et al. [2011] used spatially resolved small-angle X-ray scattering, detecting both collagen fibril periodicity and mineralization level in caries-infected, caries-affected and sound dentin. Even though the authors concluded that the collagen network is conserved in abundance and orientation even after relatively high (up to $30 \%$ ) loss of min- 

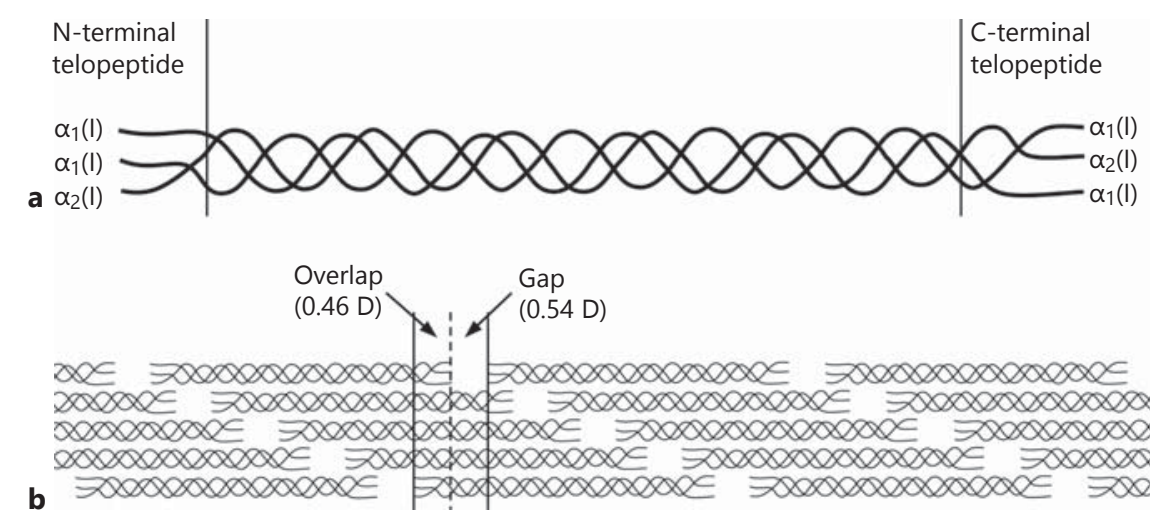

Fig. 4. Basic structure of type I collagen. a Intact type I collagen molecule (tropocollagen) with two $\alpha_{1}(\mathrm{I})$ chains and one $\alpha_{2}(\mathrm{I})$ chain. The non-helical terminal ends, telopeptides, are required for correct molecular registration and major cross-link formation to develop fibrillar structures. Cleavage of telopeptides with telopeptidase activity leaves behind the helical part of the molecule (atelocollagen). Loss of telopeptides or impaired cross-linking can significantly affect connective tissue structural integrity [Orgel et al., 2000], as atelocollagen is less thermally stable and more prone to local unfolding and degradation by non-specific proteases. Loss of C-terminal telopeptide has also been shown to expose the MMP binding site and subsequently lead to degradation [Perumal et al., 2008]. b The periodicity of collagen is based on overlapping arrangement of individual collagen molecules. Collagen molecular packing allows for the formation of microfibrils, a gap region with four and an overlap region with five collagen molecular segments. erals, the outcome may be more complicated. Re-evaluation of the data presented in that article demonstrates a highly significant correlation between the loss of mineral component and the loss of collagen periodicity (fig. $3 b$ ). The statistically significant loss of minerals already in caries-affected dentin is accompanied by a respective loss of collagen periodicity signal [Deyhle et al., 2011] (fig. 3c, d). Vidal et al. [2014] show that the autofluorescent signal emitted by the molecularly well-structured collagen in sound dentin is almost completely lost in caries-affected dentin. Thus, these data actually indicate that dentin collagen may be prone to structural changes already after mild demineralization in natural caries lesions.

In principle, the loss of collagen periodicity in cariesaffected and caries-infected dentin may be attributable to the telopeptidase activity of endogenous or salivary MMPs and/or cysteine cathepsins. In collagen fibril, the five collagen molecules that make up the microfibril each have $\mathrm{N}$ - and C-terminal non-helical telopeptides (fig. 4a). In the overlap region, all five molecules overlap with each other, one of them with the C-terminal telopeptide: the gap region (where intrafibrillar mineral resides) is located between the $\mathrm{N}$ - and C-terminal telopeptides of adjacent molecules (fig. $4 \mathrm{~b}$ ). Cleavage of the C- and N-terminal telopeptide (containing the carboxy- and aminoterminal cross-links, respectively [Orgel et al., 2000]) results in the loss of terminal ends of the collagen molecule. The en- zymes capable of cleaving telopeptides are collectively called telopeptidases, and in relation to dentin pathologies include at least MMP-2 and MMP-9 [Okada et al., 1995; Garnero et al., 1998, 2003; Osorio et al., 2011], cathepsin K [Garnero et al., 1998, 2003], pepsin [Walton et al., 2010] and trypsin [Mirigian et al., 2013]. Type I collagen telopeptide contains recognition sites for the gelatinase fibronectin-like domain [Steffensen et al., 1995], indicating that MMP-2 and MMP-9 telopeptidase activity may be totally separate from the gelatinolytic activity of these enzymes. It is interesting to note that neither pepsin nor trypsin have any marked cleavage activity against type I collagen helical parts [Walton et al., 2010; Mirigian et al., 2013]. Therefore, the role of gastric enzymes in the matrix degradation in erosion [Schlueter et al., 2010, 2012b] may relate to telopeptidase activity and activation of other collagenolytic enzymes [Mirigian et al., 2013], e.g. MMPs or cysteine cathepsins.

In mineralized dentin, the gap region contains intrafibrillar mineral crystals, and collagen periodicity is retained (fig. 5a, b). When dentin is experimentally demineralized e.g. with acids, the extrafibrillar mineral is removed faster [Kinney et al., 1995; Balooch et al., 2008] and the fibril periodicity is still retained [Balooch et al., 2008]. In natural caries, however, with slowly advancing demineralization and repeated demineralization-remineralization phases, removal of extrafibrillar mineral may 
Fig. 5. Proposed effect of telopeptidase activity on dentin collagen structure during demineralization. a, b Fully mineralized dentin collagen has normal type I collagen periodicity (a) with intrafibrillar mineral crystals (approximately 33\% of total dentin mineral) located in the gap regions between adjacent $\mathrm{N}$ - and C-terminal telopeptides, and larger extrafibrillar mineral crystals protecting the gap regions (b). The C-terminal telopeptide (red squares) contains the intermolecular cross-link (red lines) to the adjacent molecule's helical part (black squares). c Early demineralization occurs mainly in the interfibrillar space, possibly exposing some gap regions. Localized loss of intrafibrillar mineral enables local telopeptidase activity to cleave C-terminal telopeptide, resulting in minor loss of collagen periodicity and partial loss of intermolecular cross-links. d Advancing demineralization increases the rate of extra- and intrafibrillar demineralization, subsequently leading to loss of telopeptides with cross-links, and increases the loss of periodicity. Loss of intrafibrillar mineral and C-terminal telopeptide (increasing the width of the gap region) may decrease the ability for intrafibrillar remineralization.

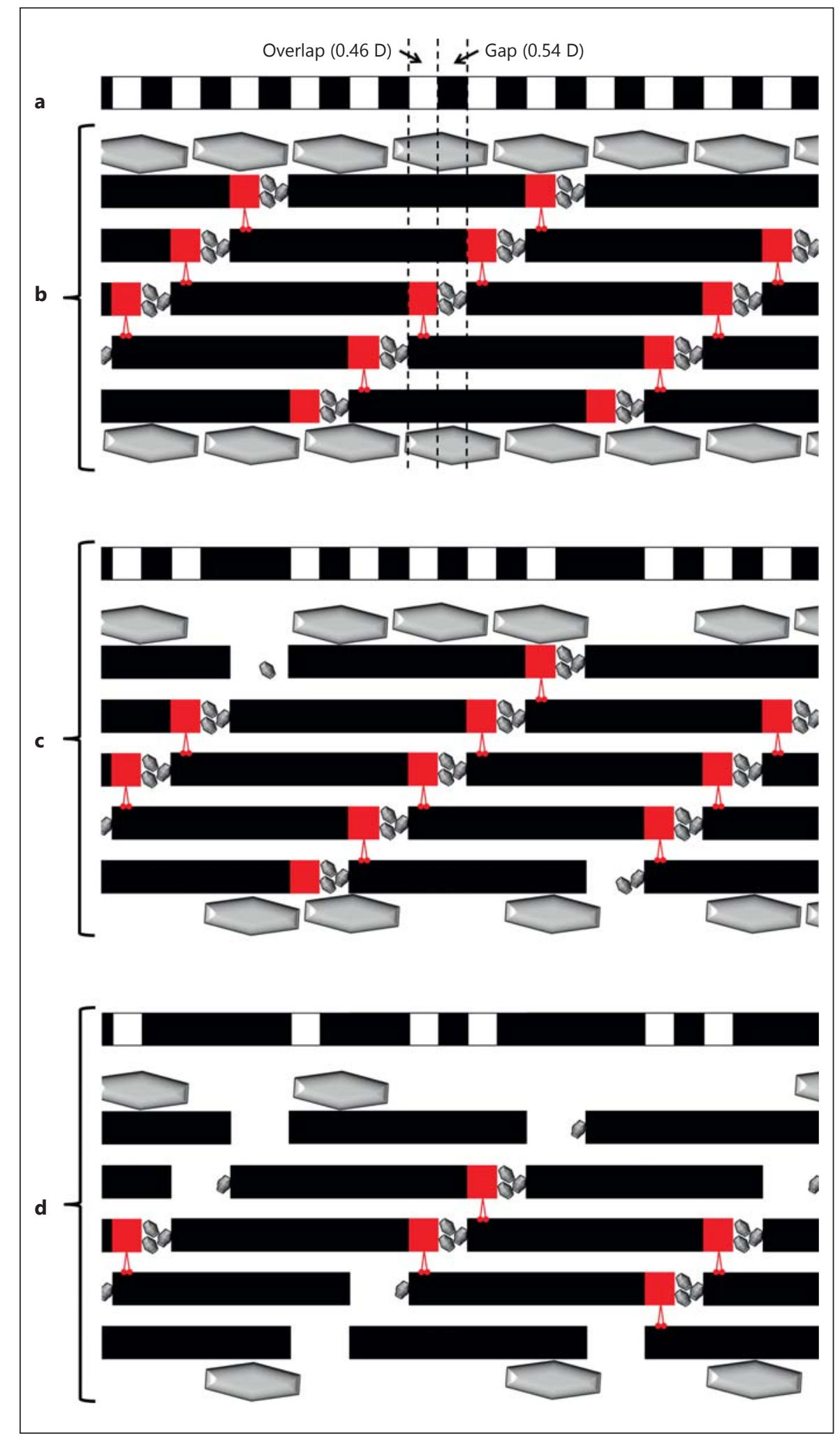


expose intrafibrillar mineral, allowing its removal at least partially. At the same time, the $\mathrm{pH}$ changes can activate endogenous MMPs and cysteine cathepsins with telopeptidase activity (at least MMP-2, MMP-9 and cathepsin K), which may cleave the C-terminal telopeptide (fig. 5c). This would lead to the loss of the fifth molecular component of the overlap region, resulting in the local loss of collagen periodicity. When demineralization advances, more intrafibrillar mineral and C-terminal telopeptides are lost with the advancing loss of periodicity (fig. 5d).

It is also possible that the activation and telopeptidase activity occurs after the removal of extrafibrillar but before the loss of intrafibrillar mineral. This is at least indirectly supported by the increase in detection of proteases with telopeptidase activity (cathepsin K, MMP-2 and MMP-9) together with the loss of collagen detection in caries-affected dentin [Vidal et al., 2014]. The loss of Cterminal telopeptide would then cause the loss of intrafibrillar mineral from the widened gap region. This could explain the gradual loss of collagen periodicity and its correlation with mineral loss in caries-affected dentin [Deyhle et al., 2011]. Since cathepsins, but not MMPs, are able to cleave N-terminal telopeptide [Garnero et al., 1998; Kafienah et al., 1998] and MMP telopeptidase activity seems to be markedly (about 10-fold) higher than cathepsin-related activity in dentin [Tezvergil-Mutluay et al., 2013], the retention of N-terminal cross-links may prevent the complete disassembly of collagen fibrils at this stage. Only later, after gradual degradation of the helical part of the collagen molecule by endogenous or - in case of caries - salivary or bacterial collagenases, will the destruction of dentin collagen matrix be completed.

Suppa et al. [2006] demonstrated reduced proteoglycan antigenicity together with loss of collagen antigenicity in caries-affected dentin. MMP-3, present in dentin [Boukpessi et al., 2008; Mazzoni et al., 2011] and known to degrade proteoglycans, has been shown to extract the proteoglycans decorin and biglycan and selectively also some phosphorylated proteins, whose presence might be important for remineralization [Boukpessi et al., 2008; Khaddam et al., 2014]. Inhibition of external MMP-3 by grape seed extracts totally and by fluorides partially abolished the release of decorin, biglycan and dentin sialoprotein from human dentin [Khaddam et al., 2014]. As papain gel, also known to extract proteoglycans, decreases the mechanical properties of demineralized dentin collagen and might even affect the collagen fibril structure [Bertassoni and Marshall, 2009], MMP-3 might contribute to the loss of carious dentin matrix mechanical properties and reduce the ability for natural remineralization.

MMPs and Other Matrix Proteinases in Relation to Cariology

\section{Host Proteases and Erosion}

A sequence similar to that in caries [Tjäderhane et al., 1998a] occurs in erosive challenges. The $\mathrm{pH}$ fall and neutralization by salivary buffers leads to demineralization, exposing the organic matrix, and is at the same time expected to lead to the activation and functional activity of proteases. These active proteases can degrade the demineralized organic matrix (DOM), thus increasing the rate of erosion progression [Kleter et al., 1994; Ganss et al., 2001]. Since erosive demineralization does not involve bacteria, host-derived proteases (from either saliva or dentin) might be more involved in the degradation of the DOM in erosive lesions. Considering that cysteine cathepsins can degrade collagen at acidic $\mathrm{pH}$ while MMPs are functional at neutral environment and also that cysteine cathepsins can activate MMPs [Nagase, 1997], the interplay between these collagenolytic enzymes might govern the fate of the DOM during erosive demineralization. However, the relative contribution of each of these classes of collagenolytic enzymes for the progression of erosion is not known so far. The use of specific inhibitors for these distinct classes of enzymes might be a good tool to better understand their role in the progression of erosive lesions.

The role of collagenolytic enzymes for the progression of erosive demineralization is supported by clinical data showing higher activity of collagenase in saliva of bulimic volunteers with erosion when compared with controls [Schlueter et al., 2012a]. Thus, a logical approach that was recently proposed to reduce dentin erosive demineralization is the use of protease inhibitors to preserve the DOM (fig. 6), which has been shown to reduce further mineral loss [Buzalaf et al., 2012; Kato et al., 2012].

Among the different types of inhibitors of collagenolytic enzymes, CHX and epigallocatechin gallate (EGCG) have been evaluated as part of preventive strategies to reduce erosive dentin demineralization, using in situ protocols. CHX is able to inhibit both MMPs [Gendron et al., 1999] and cysteine cathepsins [Scaffa et al., 2012], while EGCG inhibits MMPs [Demeule et al., 2000] but not cysteine cathepsins [Katunuma et al., 2006]. In these studies, the inhibitors were included in rinse solutions [Kato et al., 2009; Magalhães et al., 2009] or gels for topical application [Kato et al., 2010]. When the inhibitors were included in rinse solutions, significant (around 30-40\%) reduction of dentin loss was achieved when compared with control for the rinses performed for $1 \mathrm{~min}$ after each erosive challenge [Kato et al., 2009; Magalhães et al., 2009]. However, the need of rinsing immediately after each ero- 


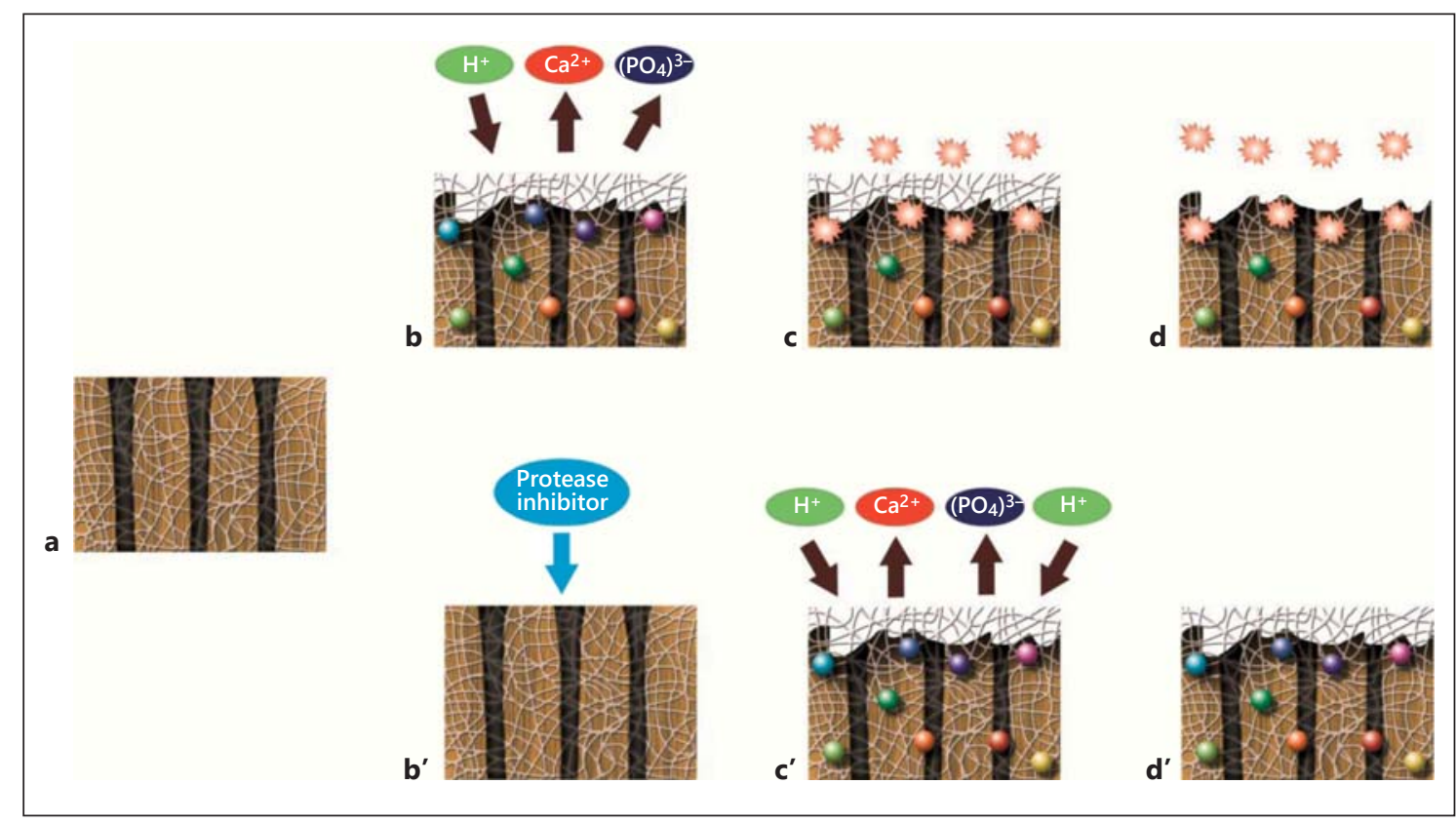

Fig. 6. Mechanism of action of protease inhibitors against dentin erosive demineralization. Spheres indicate inactive proteases and asterisks indicate active proteases. a Sound dentin. After erosive challenge, the dentin surface is demineralized, exposing the collagen fibrils (b). At the same time, salivary and dentin proteases are activated (c) and degrade the DOM (d), allowing erosion to progress. When protease inhibitors are used $\left(\mathbf{b}^{\prime}\right)$, the DOM is not degraded $\left(\mathbf{c}^{\prime}\right)$ and prevents further demineralization during the subsequent erosive challenges $\left(\mathbf{d}^{\prime}\right)$. sive challenge is not practical for clinical application. To increase the contact of the protease inhibitors with dentin, they were included in gel formulations that were applied on the specimens for 1 min only once, before the first erosive challenge. This single 1-minute treatment was able to completely prevent dentin loss evaluated by profilometry [Kato et al., 2010]. Thus, it seems that the increased time of contact of the inhibitors with dentin by the use of gel formulations plays an important role for the preventive effect of the product. Further studies should evaluate for how long the protective effect of the gels lasts, in order to propose protocols for clinical use.

The above-mentioned in situ studies indicate that compounds classically known for their ability to inhibit collagenolytic enzymes are effective to prevent dentin erosive demineralization. However, in these studies, the response variable employed was profilometry that evaluates dentin loss (mineralized plus organic tissue), but not the degradation of the DOM itself. A recent in vitro proofof-concept study showed that release of hydroxyproline in the incubation solution (artificial saliva containing bacterial collagenase from Clostridium histolyticum) was significantly reduced when the specimens previously demineralized with citric acid $(0.87 \mathrm{M}, \mathrm{pH} 2.3,36 \mathrm{~h})$ were treated with gels containing EGCG $(400 \mu \mathrm{M})$ or CHX $(0.012 \%)$ for $1 \mathrm{~min}$ [Kato et al., 2012]. This study provides evidence that the protease inhibitors evaluated are able to reduce the DOM degradation.

An interesting finding of the study by Kato et al. [2012] was that treatment with a gel containing $1.23 \% \mathrm{NaF}$, included as a control, significantly reduced the DOM degradation. Due to this, it was hypothesized that besides its well-known action on the de-remineralization processes [Buzalaf et al., 2011], fluoride could also inhibit MMPs. This hypothesis was confirmed using gelatin zymography that revealed decreased activities of proactive and active forms of salivary and purified human MMPs by incubation with $\mathrm{NaF}$ in a dose-response manner [Kato et al., 2014]. These findings might help to explain why the effect of fluoride against dentin erosion depends on the maintenance of the DOM [Ganss et al., 2004] and provide new insights into the mechanism of action of fluoride for the prevention of both caries and erosion in dentin.

In summary, the use of protease inhibitors seems to emerge as a potential preventive tool against dentin erosive demineralization. However, the knowledge available so far comes from in vitro and in situ studies. Clinical trials are needed to confirm the relevance of this preventive 
measure and to establish protocols for its clinical use. Moreover, studies unraveling the relative importance of distinct collagenolytic enzymes for the degradation of the DOM under conditions of erosive demineralization are necessary.

\section{Host Proteases and Composite Resin Bonding}

Restoration of caries lesions is increasingly accomplished by using methylmethacrylate-based resins. Resindentin bonding mechanisms, whether etch-and-rinse (ER) or self-etch (SE), are based on the formation of a hybrid layer that couples methylmethacrylate dental adhesives/resin composites to the underlying dentin. Except for the resin tags extending some micrometers into dentinal tubules, which usually comprise just a few percent of bonded surface areas, the only physical continuity between the hybrid layer and the underlying dentin (either sound or caries-affected) are the collagen fibrils.

Chemical amendments of adhesive formulations by the inclusion of more hydrophilic monomers and acidic resin monomers, combined with solvents, rendered the dental adhesives more compatible to interact with the naturally moist dentin surface, yielding significant improvements in the immediate bonding effectiveness of most current adhesive systems [Tay and Pashley, 2003]. However, the incorporation of hydrophilic and acidic resin monomers in contemporary ER and SE adhesives are claimed to bring potential problems to the long-term performance of final restorations. Several laboratory and ex vivo/in vivo studies have reported remarkable drops of resin-dentin bond strength after short- and long-term investigations [Sano et al., 1999; Hashimoto et al., 2000; De Munck et al., 2003; Armstrong et al., 2004; Hebling et al., 2005; Carrilho et al., 2007a, b; Abdalla, 2010; Garcia-Godoy et al., 2010; Hashimoto et al., 2010; Heintze et al., 2010]. Dramatic loss of effectiveness of some adhesives in terms of mechanical cohesion and/or dentinal sealing capacity has been also shown when non-carious cervical lesions were evaluated [Peumans et al., 2005; Heintze et al., 2010]. Failure of resin-adhesive restorations is often followed by secondary caries [Tyas, 2005; SunnegårdhGrönberg et al., 2009], further loss of tooth structure, increased rate of pulp destruction, and eventually need for endodontic, restorative and prosthetic treatments [Abbott, 2004; Hickel et al., 2005]. Depending on factors such as the size of the restoration, tooth location and the patient's general health/features, the life span of resin composite restorations is roughly half of that reported for those with similar features but made of amalgam [Mjör et al., 2000; Van Nieuwenhuysen et al., 2003].

The durability of hybrid layers ultimately depends on the intrinsic resistance of their individual components with regard to degradation mechanisms. Although the exact mechanism responsible for hybrid layer degradation is not completely understood, it has been thought that it involves extraction of poorly converted resins from the bonded dentin matrix via water-filled nanometersized voids within hybrid layers, followed by an enzymatic attack of exposed collagen fibrils [Tjäderhane et al., 2013b].

A series of recent studies have identified potential and relevant implications of dentin endogenous enzymes in the lack of integrity of resin-dentin bonded interfaces. By assaying the collagenolytic activity of mineralized dentin powder using fluorescein-labeled type I collagen from bovine skin, Pashley et al. [2004] demonstrated an intrinsic proteolytic activity for human mineralized dentin. These authors speculated that such proteolytic activity could be exerted by dentinal MMPs, which on that occasion had already been shown to be potentially expressed in the dentin-pulp complex. When some years later Tersariol et al. [2010] and Nascimento et al. [2011] demonstrated that cysteine cathepsins could also be expressed by mature human odontoblasts and pulp tissues extracted from sound and carious teeth, the participation of this class of proteinases in the enzymatic degradation of denuded collagen within hybrid layers started also being hypothesized. In addition, the study by Tersariol et al. [2010] showed a positive correlation between the enzymatic activity of dentinal cysteine cathepsins and MMPs, which suggests that these classes of enzymes may act synergistically in degradation of dentin matrix in different physiological and pathological processes.

Over the last decade, after the groundbreaking report by Pashley et al. [2004] that mineralized dentin does have an intrinsic proteolytic activity, several papers have described different techniques to confirm that host-derived enzymes play a role in the degradation of the hybrid layer collagenous matrix. The finding that the well-known antimicrobial CHX exhibits also a potent anti-MMP-2, antiMMP-8 and anti-MMP-9 activity [Gendron et al., 1999] encouraged the determination of whether CHX could stabilize the organic matrix of resin-dentin bonds. This led to numerous ex vivo [Carrilho et al., 2007a; Breschi et al., 2009; Stanislawczuk et al., 2009; Breschi et al., 2010; Manfro et al., 2012] and in vivo studies [Hebling et al., 2005; Brackett et al., 2007; Carrilho et al., 2007b; Brackett et al., 2009] demonstrating that CHX has beneficial ef- 
fects on the preservation of resin-dentin bonds, thereby offering a valuable alternative to clinicians who seek to delay the degradation process of adhesive restorations. The success of CHX in preserving the integrity of resindentin bonds was firstly credited to its ability to inhibit the proteolytic activity of MMPs, but it was also shown to be effective in controlling the activity of dentinal cysteine cathepsins [Scaffa et al., 2012].

Zymography assays performed on protein dentin extracts after treating dentin powder with different procedures that mimic bonding procedures (i.e. acid-etching, primer or adhesive treatment) have shown that the gelatinolytic activity of dentin can be remarkably increased with regard to that of mineralized dentin [Breschi et al., 2010]. On the contrary, when dentin is treated with proteinase inhibitors before being resin-hybridized (i.e. $\mathrm{CHX}$, galardin, EDTA, tetracyclines and derivatives, quaternary ammonium compounds), it exhibits consistently lower or no proteolytic activity if compared to that of mineralized dentin [Carrilho, 2012; Tjäderhane et al., 2013b].

Since MMPs and cysteine cathepsins are secreted to the extracellular matrix compartment as proenzymes, thus being inactive, it is not expected that in physiological conditions they can exert a substantial function. Nonetheless, when dentin is prepared to be hybridized with dental resins, it is subjected to a series of acidic chemicals that may be implicated as possible activators of dentinal proteinases [Tjäderhane et al., 2013b]. Although MMPs are prone to cleave collagen and other extracellular matrix components at neutral $\mathrm{pH}$, they were shown to be activated at low $\mathrm{pH}$ around 2.5-4.5 [Tjäderhane et al., 1998a]. Conversely, cysteine cathepsins are auto-activated and functional in low $\mathrm{pH}$, and most are considered unstable and inactive in neutral $\mathrm{pH}$ [Turk et al., 2000]. This low $\mathrm{pH}$ dependence may explain why mild acidic treatment of dentin with primer solutions of ER or SE dental adhesives can indeed activate dentin proteinases, making them likely apt to degrade the collagen, which is eventually exposed and/or denatured with the hybrid layers [Mazzoni et al., 2006; Nishitani et al., 2006; Mazzoni et al., 2013].

Evidence for the involvement of MMPs (much more numerous) and cysteine cathepsins in the degradation of collagen within hybrid layers has been mostly attained from indirect demonstration, such as by treating dentin with proteinase inhibitors prior to or during the bonding procedures. However, using a correlative approach with an ELISA assay and in situ zymography, Mazzoni et al. [2012b] were able to quantify and localize MMP activity within the hybrid layer created by an ER adhesive. This was performed using quenched fluorescent-labeled gelatin showing intense and precise fluorescent localization, indicating enzyme activity within the hybrid layer [Mazzoni et al., 2012b]. Even though these techniques have not been yet performed with SE dental adhesives or to detect the activity of cysteine cathepsins, we truly believe that they could show similar results for both experimental conditions.

Understanding the function of the enzymes responsible for the hydrolysis of collagen within hybrid layers has prompted several approaches to retain hybrid layer integrity and strong dentin bonding. Undoubtedly $\mathrm{CHX}$ has been so far the most successful substance used for this purpose. The excellent results of CHX application are consistent mainly because they have been independently obtained from laboratories all over the world, which provides a reliable body of evidence on its effect on hybrid layer preservation. For a comprehensive overview of current knowledge on the effect of exogenous proteinase inhibitors and different other approaches to preserve the integrity of hybrid layers, the reader is referred to recent reviews [Carrilho, 2012; Reis et al., 2013; Tjäderhane et al., 2013b]. In a nutshell, these reviews show that mainly with regard to sound dentin, the prevention of collagen matrix degradation may be achievable with clinically applicable techniques and commercially available materials.

Most of the studies, not to say all, which have been performed to understand the role of proteinases in the lack on durability of hybrid layers have chosen sound dentin as the major object of investigation. Nevertheless it should be kept in mind that with the recent and growing acceptance of minimally invasive dentistry, many bonding protocols are actually performed in caries-affected dentin. Therefore, we should start concentrating on how to enhance bonding performance of commercial adhesives to this substrate, and on alternatives to make this resin-adhesive interface resilient to degradation over time. We truly believe that by improving our knowledge of the role and interplay of proteases in this substrate may help us to determine clinical strategies to produce durable adhesive restorations, regardless whether the bonding procedures are restricted to sound dentin or are extended to cariesaffected one.

\section{Conclusions and Future Perspectives}

The discovery of the presence, identification and functional activity assessment of endogenous collagenolytic dentinal enzymes has marked the beginning of the era of dentin degradomics. The evidence of the significant role 
of these enzymes in the conditions involving the complete or partial exposure of dentin collagenous matrix is steadily increasing. A more detailed picture of the events will further improve our understanding of the processes and the players involved. That, in turn, will help us to benefit from the inhibition of unwanted and the enhancement of beneficial processes.

To achieve this goal, the enzyme function has to be studied in or as close as possible to their natural environment, where the natural substrates are available. For example, what is - if any - the role of dentin-bound dentin phosphoprotein (DPP) in the remineralization of caries-affected or erosion-demineralized dentin? If it is important, how do we best preserve it in partially or totally demineralized dentin? The binding of DPP on collagen is highly selective: in turkey tendon fibril it binds to the collagen gap region, where it has been suggested to regulate mineral deposition within the gap regions [Traub et al., 1992]. Separation of DPP from dentin collagen is relatively difficult and requires acid phosphatase [Saito et al., 1997]. Even though MMP-2 and MMP-20 have been shown to process dentin sialophosphoprotein into DPP, these enzymes fail to further degrade DPP [Yamakoshi et al., 2006], indicating that MMP inhibition would have no direct relevance to DPP retention in dentin. However, the loss of dentinal telopeptides may well result in the loss of DPP, thus seriously reducing the dentin remineralization capacity. The role of telopeptides in remineralization is supported by the inability of cross-linked DPP to mineralize collagen in which telopeptides have been removed with pepsin, in contrast to native collagen [Saito et al., 2000]. Therefore, inhibition of enzymes with telopeptidase activity might help to preserve the collagen telopeptides and retain the natural ability for physiological remineralization.
Different enzymes may have a different role or relative importance depending on the situation. Demineralization of dentin in caries lesions may take a very long time, while in erosion or dentin acid etching in restorative processes it occurs rapidly, even within seconds. The sequence of degradation may be totally different, with different enzymes playing differential roles at different phases of the process. In the dentin degradomic approach, the selection of substrate may be equally important as the enzyme or inhibitor to be studied. The activity of cathepsin $\mathrm{K}$, for example, is highly regulated by the presence of different glycosaminoglycans [Mazzoni et al., 2012a]. If this is also the case in dentin, stromelysins with proteoglycanase activity (e.g. MMP-3) might regulate cathepsin K activity by selectively degrading dentin NCPs. Since not only the enzymes but also other NCP components may vary between species [Tjäderhane et al., 2012], use of dentin - especially human dentin - whenever possible is essential to allow correct interpretation of the results.

\section{Acknowledgements}

The authors thank FAPESP (2012/03925-2 and 2007/08389-3) and $\mathrm{CNPq}(401347 / 2012-5)$ (P.I. M.A.R. Buzalaf), $\mathrm{CNPq}$ (306100/2010-0) (P.I. M. Carrilho), University Paris Descartes and Fondation de l'Avenir (P.I. C. Chaussain), and the Academy of Finland (256990) (P.I. L. Tjäderhane) for financial support.

\section{Disclosure Statement}

The authors declare no conflicts of interest. The funders had no role in study design, data collection and analysis, decision to publish, or preparation of the manuscript.

\section{References}

\footnotetext{
Abbott PV: Assessing restored teeth with pulp Balooch M, Habelitz S, Kinney JH, Marshall SJ, and periapical diseases for the presence of cracks, caries and marginal breakdown. Aust Dent J 2004;49:33-39.

Abdalla AI: Effect of long-term water aging on microtensile bond strength of self-etch adhe- Bertassoni LE, Habelitz S, Kinney JH, Marshall SJ, sives to dentin. Am J Dent 2010;23:29-33.

-Arends J, Ruben J, Jongebloed WL: Dentine caries in vivo. Combined scanning electron microscopic and microradiographic investigation. Caries Res 1989;23:36-41.

-Armstrong SR, Vargas MA, Chung I, Pashley DH, Campbell JA, Laffoon JE, Qian F: Resin-dentin interfacial ultrastructure and microtensile dentin bond strength after five-year water storage. Oper Dent 2004;29:705-712. Marshall GW: Mechanical properties of mineralized collagen fibrils as influenced by demineralization. J Struct Biol 2008;162:404410 . Marshall GW Jr: Biomechanical perspective on the remineralization of dentin. Caries Res 2009;43:70-77.

-Bertassoni LE, Habelitz S, Marshall SJ, Marshall GW: Mechanical recovery of dentin following remineralization in vitro - an indentation study. J Biomech 2011;44:176-181.

-Bertassoni LE, Marshall GW: Papain-gel degrades intact nonmineralized type I collagen fibrils. Scanning 2009;31:253-258.

Boukpessi T, Menashi S, Camoin L, ten Cate JM, Goldberg M, Chaussain-Miller C: The effect of stromelysin-1 (MMP-3) on non-collagenous extracellular matrix proteins of demineralized dentin and the adhesive properties of restorative resins. Biomaterials 2008;29: 4367-4373.

Boushell LW, Kaku M, Mochida Y, Bagnell R, Yamauchi M: Immunohistochemical localization of matrixmetalloproteinase-2 in human coronal dentin. Arch Oral Biol 2008;53:109_ 116.

Boushell LW, Nagaoka H, Nagaoka H, Yamauchi M: Increased matrix metalloproteinase- 2 and bone sialoprotein response to human coronal caries. Caries Res 2011;45:453-459.
}

MMPs and Other Matrix Proteinases in Relation to Cariology 
Brackett MG, Tay FR, Brackett WW, Dib A, Dipp FA, Mai S, Pashley DH: In vivo chlorhexidine stabilization of hybrid layers of an acetonebased dentin adhesive. Oper Dent 2009;34: 379-383.

- Brackett WW, Tay FR, Brackett MG, Dib A, Sword RJ, Pashley DH: The effect of chlorhexidine on dentin hybrid layers in vivo. Oper Dent 2007;32:107-111

- Breschi L, Cammelli F, Visintini E, Mazzoni A, Vita F, Carrilho M, Cadenaro M, Foulger S, Tay FR, Pashley DH: Influence of chlorhexidine concentration on the durability of etchand-rinse dentin bonds: a 12-month in vitro study. J Adhes Dent 2009;11:191-198.

Breschi L, Mazzoni A, Nato F, Carrilho M, Visintini E, Tjäderhane L, Ruggeri A Jr, Tay FR, Dorigo Ede S, Pashley DH: Chlorhexidine stabilizes the adhesive interface: a 2 -year in vitro study. Dent Mater 2010;26:320-325.

Buzalaf MA, Kato MT, Hannas AR: The role of matrix metalloproteinases in dental erosion. Adv Dent Res 2012;24:72-76.

- Buzalaf MA, Pessan JP, Honório HM, ten Cate JM: Mechanisms of action of fluoride for caries control. Monogr Oral Sci 2011;22:97-114.

Carrilho MR: Can exogenous protease inhibitors control dentin matrix degradation? J Dent Res 2012;91:1099-1102.

Carrilho MR, Carvalho RM, De Goes MF, Hipolito V, Geraldeli S, Tay FR, Pashley D, Tjäderhane L: Chlorhexidine preserves dentin bond in vitro. J Dent Res 2007a;86:90-94.

-Carrilho MR, Geraldeli S, Tay F, de Goes MF, Carvalho RM, Tjäderhane L, Reis AF, Hebling J, Mazzoni A, Breschi L, Pashley D: In vivo preservation of the hybrid layer by chlorhexidine. J Dent Res 2007b;86:529-533.

-Carrilho MR, Tay FR, Donnelly AM, Agee KA, Tjäderhane L, Mazzoni A, Breschi L, Foulger S, Pashley DH: Host-derived loss of dentin matrix stiffness associated with solubilization of collagen. J Biomed Mater Res B Appl Biomater 2009;90:373-380.

Charadram N, Farahani RM, Harty D, Rathsam C, Swain MV, Hunter N: Regulation of reactionary dentin formation by odontoblasts in response to polymicrobial invasion of dentin matrix. Bone 2012;50:265-275.

-Chaussain C, Boukpessi T, Khaddam M, Tjäderhane L, George A, Menashi S: Dentin matrix degradation by host matrix metalloproteinases: inhibition and clinical perspectives toward regeneration. Front Physiol 2013;4: 308.

-Cooper PR, McLachlan JL, Simon S, Graham LW, Smith AJ: Mediators of inflammation and regeneration. Adv Dent Res 2011;23:290-295.

-Dayan D, Binderman I, Mechanic GL: A preliminary study of activation of collagenase in carious human dentine matrix. Arch Oral Bio 1983;28:185-187.

-Dechichi P, Biffi JC, Moura CC, de Ameida AW: A model of the early mineralization process of mantle dentin. Micron 2007;38:486-491.

-Demeule M, Brossard M, Pagé M, Gingras D, Béliveau R: Matrix metalloproteinase inhibition by green tea catechins. Biochim Biophys Acta 2000;1478:51-60.

De Munck J, van Meerbeek B, Yoshida Y, Inoue S, Vargas M, Suzuki K, Lambrechts P, Vanherle G: Four-year water degradation of totaletch adhesives bonded to dentin. J Dent Res 2003;82:136-140.

Deyhle H, Bunk O, Müller B: Nanostructure of healthy and caries-affected human teeth. Nanomedicine 2011;7:694-701.

Dickinson DP: Cysteine peptidases of mammals: their biological roles and potential effects in the oral cavity and other tissues in health and disease. Crit Rev Oral Biol Med 2002;13:238 275.

Findeisen P, Neumaier M: Functional protease profiling for diagnosis of malignant disease. Proteomics Clin Appl 2012;6:60-78.

Ganss C, Klimek J, Schäffer U, Spall T: Effectiveness of two fluoridation measures on erosion progression in human enamel and dentine in vitro. Caries Res 2001;35:325-330.

Ganss C, Klimek J, Starck C: Quantitative analysis of the impact of the organic matrix on the fluoride effect on erosion progression in human dentine using longitudinal microradiography. Arch Oral Biol 2004;49:931-935.

Garcia-Godoy F, Kramer N, Feilzer AJ, Frankenberger R: Long-term degradation of enamel and dentin bonds: 6-year results in vitro vs. in vivo. Dent Mater 2010;26:1113-1118.

- Garnero P, Borel O, Byrjalsen I, Ferreras M, Drake FH, McQueney MS, Foged NT, Delmas PD, Delaissé JM: The collagenolytic activity of cathepsin $\mathrm{K}$ is unique among mammalian proteinases. J Biol Chem 1998;273:3234732352.

- Garnero P, Ferreras M, Karsdal MA, Nicamhlaoibh R, Risteli J, Borel O, Qvist P, Delmas PD, Foged NT, Delaissé JM: The type I collagen fragments ICTP and CTX reveal distinct enzymatic pathways of bone collagen degradation. J Bone Miner Res 2003;18:859-867.

-Gendron R, Grenier D, Sorsa T, Mayrand D: Inhibition of the activities of matrix metalloproteinases 2, 8, and 9 by chlorhexidine. Clin $\mathrm{Di}$ agn Lab Immunol 1999;6:437-439.

Golub EE: Role of matrix vesicles in biomineralization. Biochim Biophys Acta 2009;1790: 1592-1598.

Hannas AR, Pereira JC, Granjeiro JM, Tjäderhane $\mathrm{L}$ : The role of matrix metalloproteinases in oral environment. Acta Odontol Scand 2007; 65:1-13.

-Hashimoto M, Fujita S, Nagano F, Ohno H, Endo $\mathrm{K}$ : Ten-years degradation of resin-dentin bonds. Eur J Oral Sci 2010;118:404-410.

Hashimoto M, Ohno H, Kaga M, Endo K, Sano H, Oguchi $\mathrm{H}$ : In vivo degradation of resin-dentin bonds in humans over 1-3 years. J Dent Res 2000;79:1385-1391.

-Hebling J, Pashley DH, Tjäderhane L, Tay FR: Chlorhexidine arrests subclinical degradation of dentin hybrid layers in vivo. J Dent Res 2005;84:741-746.

-Hedenbjörk-Lager A, Bjørndal L, Gustafsson A, Sorsa T, Tjäderhane L, Åkerman S, Ericson D:
Caries correlates strongly to salivary levels of MMP-8. Caries Res 2015;49:1-8.

Heintze SD, Ruffieux C, Rousson V: Clinical performance of cervical restorations - a metaanalysis. Dent Mater 2010;26:993-1000.

-Hickel R, Kaaden C, Paschos E, Buerkle V, García-Godoy F, Manhart J: Longevity of occlusally-stressed restorations in posterior primary teeth. Am J Dent 2005;18:198-211.

-Hietala EL, Tjäderhane L, Larmas M: Dentin caries recording with Schiff's reagent, fluorescence and back scattered electron image. J Dent Res 1993;72:1588-1592.

-Ito S, Saito T, Tay FR, Carvalho RM, Yoshiyama M, Pashley DH: Water content and apparent stiffness of non-caries versus caries-affected human dentin. J Biomed Mater Res B Appl Biomater 2005;72:109-116.

-Kafienah W, Brömme D, Buttle DJ, Croucher LJ, Hollander AP: Human cathepsin K cleaves native type I and II collagens at the N-terminal end of the triple helix. Biochem J 1998; 331:727-732.

-Kato MT, Bolanho A, Zarella BL, Salo T, Tjäderhane L, Buzalaf MA: Sodium fluoride inhibits matrix MMP-2 and MMP-9. J Dent Res 2014; 93:74-77.

Kato MT, Leite AL, Hannas AR, Buzalaf MA: Gels containing MMP inhibitors prevent dental erosion in situ. J Dent Res 2010;89:468-472.

Kato MT, Leite AL, Hannas AR, Calabria MP, Magalhães AC, Pereira JC, Buzalaf MA: Impact of protease inhibitors on dentin matrix degradation by collagenase. J Dent Res 2012; 91:1119-1123.

Kato MT, Magalhães AC, Rios D, Hannas AR, Attin T, Buzalaf MA: Protective effect of green tea on dentin erosion and abrasion. J Appl Oral Sci 2009; 17:560-564.

- Katunuma N, Ohashi A, Sano E, Ishimaru N, Hayashi Y, Murata E: Catechin derivatives: specific inhibitor for caspases-3, 7 and 2, and the prevention of apoptosis at the cell and animal levels. FEBS Lett 2006;580:741-746.

Khaddam M, Salmon B, Le Denmat D, Tjäderhane L, Menashi S, Chaussain C, Rochefort GY, Boukpessi T: Grape seed extracts inhibit dentin matrix degradation by MMP-3. Front Physiol 2014;5:425.

- Kinney JH, Balooch M, Haupt DL Jr, Marshall SJ, Marshall GW Jr: Mineral distribution and dimensional changes in human dentin during demineralization. J Dent Res 1995;74:11791184.

Kinney JH, Habelitz S, Marshall SJ, Marshall GW: The importance of intrafibrillar mineralization of collagen on the mechanical properties of dentin. J Dent Res 2003;82:957-961.

-Kinney JH, Pople JA, Driessen CH, Breunig TM, Marshall GW, Marshall SJ: Intrafibrillar mineral may be absent in dentinogenesis imperfecta type II (DI-II). J Dent Res 2001;80:15551559.

Kleter GA, Damen JJ, Everts V, Niehof J, ten Cate JM: The influence of the organic matrix on demineralization of bovine root dentin in vitro. J Dent Res 1994;73:1523-1529. 
Kuboki Y, Ohgushi K, Fusayama T: Collagen biochemistry of the two layers of carious dentin. J Dent Res 1977;56:1233-1237.

Lauhio A, Salo T, Tjäderhane L, Lähdevirta J, Golub LM, Sorsa T: Tetracyclines in treatment of rheumatoid arthritis. Lancet 1995;346:645646.

López-Otín C, Overall CM: Protease degradomics: a new challenge for proteomics. Nat Rev Mol Cell Biol 2002;3:509-519.

-Magalhães AC, Wiegand A, Rios D, Hannas A, Attin T, Buzalaf MA: Chlorhexidine and green tea extract reduce dentin erosion and abrasion in situ. J Dent 2009;37:994-998.

- Manfro AR, Reis A, Loguercio AD, Imparato JC, Raggio DP: Effect of different concentrations of chlorhexidine on bond strength of primary dentin. Pediatr Dent 2012;34:e11-e15.

-Marshall GW, Habelitz S, Gallagher R, Balooch M, Balooch G, Marshall SJ: Nanomechanical properties of hydrated carious human dentin. J Dent Res 2001;80:1768-1771.

Martin-De Las Heras S, Valenzuela A, Overall CM: The matrix metalloproteinase gelatinase A in human dentine. Arch Oral Biol 2000;45: 757-765.

-Mazzoni A, Breschi L, Carrilho M, Nascimento FD, Orsini G, Ruggeri A, Gobbi P, Mazzotti G, Tay FR, Pashley DH, Tjäderhane L: A review on nature, role and functions of dentin non-collagenous proteins. Part II: enzymes, serum proteins and growth factors. Endod Topics 2012a;21:19-40.

-Mazzoni A, Mannello F, Tay FR, Tonti GA, Papa S, Mazzotti G, Di Lenarda R, Pashley $\mathrm{DH}$, Breschi L: Zymographic analysis and characterization of MMP-2 and -9 forms in human sound dentin. J Dent Res 2007;86: 436-440.

Mazzoni A, Nascimento FD, Carrilho M, Tersariol I, Papa V, Tjäderhane L, Di Lenarda R, Tay FR, Pashley DH, Breschi L: MMP activity in the hybrid layer detected with in situ zymography. J Dent Res 2012b;91:467-472.

Mazzoni A, Papa V, Nato F, Carrilho M, Tjäderhane L, Ruggeri A Jr, Gobbi P, Mazzotti G, Tay FR, Pashley DH, Breschi L: Immunohistochemical and biochemical assay of MMP3 in human dentine. J Dent 2011;39:231237.

-Mazzoni A, Pashley DH, Nishitani Y, Breschi L, Mannello F, Tjäderhane L, Toledano $\mathrm{M}$, Pashley EL, Tay FR: Reactivation of inactivated endogenous proteolytic activities in phosphoric acid-etched dentine by etch-andrinse adhesives. Biomaterials 2006;27:44704476.

-Mazzoni A, Pashley DH, Tay FR, Gobbi P, Orsini G, Ruggeri A Jr, Carrilho M, Tjäderhane L, Di Lenarda R, Breschi L: Immunohistochemical identification of MMP-2 and MMP-9 in human dentin: correlative FEI-SEM/TEM analysis. J Biomed Mater Res A 2009;88:697-703.

-Mazzoni A, Scaffa P, Carrilho M, Tjäderhane L, Di Lenarda R, Polimeni A, Tezvergil-Mutluay A, Tay FR, Pashley DH, Breschi L: Effects of etch-and-rinse and self-etch adhesives on dentin MMP-2 and MMP-9. J Dent Res 2013; 92:82-86.

Mirigian LS, Makareeva E, Koistinen H, Itkonen O, Sorsa T, Stenman UH, Salo T, Leikin S: Collagen degradation by tumor-associated trypsins. Arch Biochem Biophys 2013;535: 111-114.

Mjör IA, Dahl JE, Moorhead JE: Age of restorations at replacement in permanent teeth in general dental practice. Acta Odontol Scand 2000;58:97-101.

Muromachi K, Kamio N, Narita T, Annen-Kamio M, Sugiya H, Matsushima K: MMP-3 provokes CTGF/CCN2 production independently of protease activity and dependently on dynamin-related endocytosis, which contributes to human dental pulp cell migration. J Cell Biochem 2012;113:1348-1358.

Nagase H: Activation mechanisms of matrix metalloproteinases. Biol Chem 1997;378:151160.

Nakornchai S, Atsawasuwan P, Kitamura E, Surarit R, Yamauchi M: Partial biochemical characterisation of collagen in carious dentin of human primary teeth. Arch Oral Biol 2004;49: 267-273.

-Nascimento FD, Minciotti CL, Geraldeli S, Carrilho MR, Pashley DH, Tay FR, Nader HB, Salo T, Tjäderhane L, Tersariol IL: Cysteine cathepsins in human carious dentin. J Dent Res 2011;90:506-511.

Nishitani Y, Yoshiyama M, Wadgaonkar B, Breschi L, Mannello F, Mazzoni A, Carvalho RM, Tjäderhane L, Tay FR, Pashley DH: Activation of gelatinolytic/collagenolytic activity in dentin by self-etching adhesives. Eur J Oral Sci 2006; 114:160-166.

Niu LN, Zhang L, Jiao K, Li F, Ding YX, Wang DY, Wang MQ, Tay FR, Chen JH: Localization of MMP-2, MMP-9, TIMP-1, and TIMP2 in human coronal dentine. J Dent 2011;39: 536-542.

Ohgushi K, Fusayama T: Electron microscopic structure of the two layers of carious dentin. J Dent Res 1975;54:1019-1026.

Okada Y, Naka K, Kawamura K, Matsumoto T, Nakanishi I, Fujimoto N, Sato H, Seiki M: Localization of matrix metalloproteinase 9 (92-kilodalton gelatinase/type IV collagenase $=$ gelatinase $\mathrm{B})$ in osteoclasts: implications for bone resorption. Lab Invest 1995;72: 311-322.

Orgel JP, Wess TJ, Miller A: The in situ conformation and axial location of the intermolecular cross-linked non-helical telopeptides of type I collagen. Structure 2000;8:137-142.

-Orsini G, Ruggeri A Jr, Mazzoni A, Nato F, Mazzotti G, Putignano A, Tjäderhane L, Breschi L: A review on nature, role and functions of dentin non-collagenous proteins. Part I: proteoglycans and glycoproteins. Endod Topics 2012;21:1-18.

-Osorio R, Yamauti M, Osorio E, Ruiz-Requena ME, Pashley DH, Tay FR, Toledano M: Zinc reduces collagen degradation in demineralized human dentin explants. J Dent 2011;39: 148-153.
Pashley DH, Tay FR, Yiu C, Hashimoto M, Breschi L, Carvalho RM, Ito S: Collagen degradation by host-derived enzymes during aging. J Dent Res 2004;83:216-221.

- Perumal S, Antipova O, Orgel JP: Collagen fibril architecture, domain organization, and triple-helical conformation govern its proteolysis. Proc Natl Acad Sci U S A 2008;105:28242829.

-Pessoa JI, Guimarães GN, Viola NV, da Silva WJ, de Souza AP, Tjäderhane L, Line SR, Marques MR: In situ study of the gelatinase activity in demineralized dentin from rat molar teeth. Acta Histochem 2013;115:245-251.

Peumans M, Kanumilli P, De Munck J, van Landuyt K, Lambrechts P, van Meerbeek B: Clinical effectiveness of contemporary adhesives: a systematic review of current clinical trials. Dent Mater 2005;21:864-881.

- Reis A, Carrilho M, Breschi L, Loguercio AD: Overview of clinical alternatives to minimize the degradation of the resin-dentin bonds. Oper Dent 2013;38:E1-E25.

Saito T, Arsenault AL, Yamauchi M, Kuboki Y, Crenshaw MA: Mineral induction by immobilized phosphoproteins. Bone 1997;21:305311.

Saito T, Yamauchi M, Abiko Y, Matsuda K, Crenshaw MA: In vitro apatite induction by phosphophoryn immobilized on modified collagen fibrils. J Bone Miner Res 2000;15:16151619.

Sano H, Yoshikawa T, Pereira PN, Kanemura N, Morigami M, Tagami J, Pashley DH: Longterm durability of dentin bonds made with a self-etching primer, in vivo. J Dent Res 1999; 78:906-911.

-Santos J, Carrilho MR, Tervahartiala T, Sorsa T, Breschi L, Mazzoni A, Pashley D, Tay F, Ferraz $\mathrm{C}$, Tjäderhane L: Determination of matrix metalloproteinases in human radicular dentin. J Endod 2009;35:686-689.

-Scaffa PM, Vidal CM, Barros N, Gesteira TF, Carmona AK, Breschi L, Pashley DH, Tjäderhane L, Tersariol IL, Nascimento FD, Carrilho MR: Chlorhexidine inhibits the activity of dental cysteine cathepsins. J Dent Res 2012;91:420425 .

-Schlueter N, Ganss C, Pötschke S, Klimek J, Hannig C: Enzyme activities in the oral fluids of patients suffering from bulimia: a controlled clinical trial. Caries Res 2012a;46:130139.

Schlueter N, Glatzki J, Klimek J, Ganss C: Erosiveabrasive tissue loss in dentine under simulated bulimic conditions. Arch Oral Biol 2012b; 57:1176-1182.

Schlueter N, Hardt M, Klimek J, Ganss C: Influence of the digestive enzymes trypsin and pepsin in vitro on the progression of erosion in dentine. Arch Oral Biol 2010;55: 294-299.

Shimada Y, Ichinose S, Sadr A, Burrow MF, Tagami J: Localization of matrix metalloproteinases (MMPs-2, 8, 9 and 20) in normal and carious dentine. Aust Dent J 2009;54:347354. 
-Sorsa T, Tjäderhane L, Konttinen YT, Lauhio A, Salo T, Lee HM, Golub LM, Brown DL, Mäntylä P: Matrix metalloproteinases: contribution to pathogenesis, diagnosis and treatment of periodontal inflammation. Ann Med 2006; 38:306-321.

-Stanislawczuk R, Amaral RC, Zander-Grande C, Gagler D, Reis A, Loguercio AD: Chlorhexidine-containing acid conditioner preserves the longevity of resin-dentin bonds. Oper Dent 2009;34:481-490.

-Steffensen B, Wallon UM, Overall CM: Extracellular matrix binding properties of recombinant fibronectin type II-like modules of human $72-\mathrm{kDa}$ gelatinase/type IV collagenase. High affinity binding to native type I collagen but not native type IV collagen. J Biol Chem 1995;270:11555-11566.

-Sulkala M, Larmas M, Sorsa T, Salo T, Tjäderhane $\mathrm{L}$ : The localization of matrix metalloproteinase-20 (MMP-20, enamelysin) in mature human teeth. J Dent Res 2002;81:603-607.

- Sulkala M, Tervahartiala T, Sorsa T, Larmas M, Salo T, Tjäderhane L: Matrix metalloproteinase-8 (MMP-8) is the major collagenase in human dentin. Arch Oral Biol 2007;52:121-127.

- Sulkala M, Wahlgren J, Larmas M, Sorsa T, Teronen M, Salo T, Tjäderhane L: The effect of MMP inhibitors on human salivary MMP activity and caries progression in rats. J Dent Res 2001;80:1545-1549.

-Sunnegårdh-Grönberg K, van Dijken JW, Funegård U, Lindberg A, Nilsson M: Selection of dental materials and longevity of replaced restorations in Public Dental Health clinics in northern Sweden. J Dent 2009;37:673-678.

- Suppa P, Ruggeri A Jr, Tay FR, Prati C, Biasotto M, Falconi M, Pashley DH, Breschi L: Reduced antigenicity of type I collagen and proteoglycans in sclerotic dentin. J Dent Res 2006; $85: 133-137$.

- Tannure PN, Küchler EC, Falagan-Lotsch P, Amorim LM, Raggio Luiz R, Costa MC, Vieira AR, Granjeiro JM: MMP13 polymorphism decreases risk for dental caries. Caries Res 2012a;46:401-407.

- Tannure PN, Küchler EC, Lips A, Costa Mde C, Luiz RR, Granjeiro JM, Vieira AR: Genetic variation in MMP20 contributes to higher caries experience. J Dent 2012b;40:381-386.

- Tay FR, Pashley DH: Have dentin adhesives become too hydrophilic? J Can Dent Assoc 2003;69:726-731.

- Tersariol IL, Geraldeli S, Minciotti CL, Nascimento FD, Pääkkönen V, Martins MT, Carrilho MR, Pashley DH, Tay FR, Salo T, Tjäderhane L: Cysteine cathepsins in human dentinpulp complex. J Endod 2010;36:475-481.

Tezvergil-Mutluay A, Agee KA, Hoshika T, Carrilho M, Breschi L, Tjäderhane L, Nishitani Y, Carvalho RM, Looney S, Tay FR, Pashley DH: The requirement of zinc and calcium ions for functional MMP activity in demineralized dentin matrices. Dent Mater 2010;26:1059-1067.
Tezvergil-Mutluay A, Mutluay M, SeseogullariDirihan R, Agee KA, Key WO, Scheffel DL, Breschi L, Mazzoni A, Tjäderhane L, Nishitani Y, Tay FR, Pashley DH: Effect of phosphoric acid on the degradation of human dentin matrix. J Dent Res 2013;92:87-91.

Thompson JM, Agee K, Sidow SJ, McNally K, Lindsey K, Borke J, Elsalanty M, Tay FR, Pashley DH: Inhibition of endogenous dentin matrix metalloproteinases by ethylenediaminetetraacetic acid. J Endod 2012;38:62-65.

-Tjäderhane L, Carrilho MR, Breschi L, Tay FR, Pashley DH: Dentin basic structure and composition - an overview. Endod Topics 2012; 20:3-29.

Tjäderhane L, Haapasalo M: Dentin-pulp border: dynamic interface between hard and soft tissues. Endod Topics 2012;20:52-84.

- Tjäderhane L, Hietala EL, Larmas M: Mineral element analyses of carious and intact dentin by electron probe microanalyser combined with back-scattered electron image. J Dent Res 1995;74:1770-1774.

Tjäderhane L, Larjava H, Sorsa T, Uitto VJ, Larmas M, Salo T: The activation and function of host matrix metalloproteinases in dentin matrix breakdown in caries lesions. J Dent Res 1998a;77:1622-1629.

Tjäderhane L, Nascimento FD, Breschi L, Mazzoni A, Tersariol ILS, Geraldeli S, TezvergilMutluay A, Carrilho MR, Carvalho RM, Tay FR, Pashley DH: Optimizing dentin bond durability: control of collagen degradation by matrix metalloproteinases and cysteine cathepsins. Dent Mater 2013a;29:116-135.

- Tjäderhane L, Nascimento FD, Breschi L, Mazzoni A, Tersariol ILS, Geraldeli S, TezvergilMutluay A, Carrilho MR, Carvalho RM, Tay FR, Pashley DH: Strategies to prevent hydrolytic degradation of the hybrid layer - a review. Dent Mater 2013b;29:999-1011.

Tjäderhane L, Palosaari H, Sulkala M, Wahlgren J, Salo T: The expression of matrix metalloproteinases (MMPs) in human odontoblasts; in Ishikawa T, Takahashi K, Maeda T, Suda H, Shimono M, Inoue T (eds): Proceedings of the International Conference on Dentin/Pulp Complex 2001. Tokyo, Quintessence Publishing, 2002, pp 45-51.

Tjäderhane L, Salo T, Larjava H, Larmas M, Overall CM: A novel organ culture method to study the function of human odontoblasts in vitro: gelatinase expression by odontoblasts is differentially regulated by TGF-beta1. J Dent Res 1998b;77:1486-1496.

-Tjäderhane L, Sulkala M, Sorsa T, Teronen O, Larmas M, Salo T: The effect of MMP inhibitor metastat on fissure caries progression in rats. Ann N Y Acad Sci 1999;878:686-688.
Toledano M, Aguilera FS, Yamauti M, Ruiz-Requena ME, Osorio R: In vitro load-induced dentin collagen-stabilization against MMPs degradation. J Mech Behav Biomed Mater 2013;27:10-18.

Toledano M, Nieto-Aguilar R, Osorio R, Campos A, Osorio E, Tay FR, Alaminos M: Differential expression of matrix metalloproteinase-2 in human coronal and radicular sound and carious dentine. J Dent 2010;38: 635-640.

Traub W, Jodaikin A, Arad T, Veis A, Sabsay B: Dentin phosphophoryn binding to collagen fibrils. Matrix 1992;12:197-201.

- Turk V, Stoka V, Vasiljeva O, Renko M, Sun T, Turk B, Turk D: Cysteine cathepsins: from structure, function and regulation to new frontiers. Biochim Biophys Acta 2012;1824: 68-88.

Turk B, Turk D, Turk V: Lysosomal cysteine proteases: more than scavengers. Biochim Biophys Acta 2000;1477:98-111.

Tyas MJ: Placement and replacement of restorations by selected practitioners. Aust Dent J 2005;50:81-89.

-Van Nieuwenhuysen JP, D’Hoore W, Carvalho J, Qvist V: Long-term evaluation of extensive restorations in permanent teeth. J Dent 2003; 31:395-405.

van Strijp AJ, Jansen DC, DeGroot J, ten Cate JM, Everts V: Host-derived proteinases and degradation of dentine collagen in situ. Caries Res 2003;37:58-65.

- Vidal CM, Tjäderhane L, Scaffa PM, Tersariol IL, Pashley D, Nader HB, Nascimento FD, Carrilho MR: Abundance of MMPs and cysteine cathepsins in caries-affected dentin. J Dent Res 2014;93:269-274.

Vitorino R, de Morais Guedes S, Ferreira R, Lobo MJC, Duarte J, Ferrer-Correia AJ, Tomer KB, Domingues PM, Amado FML: Two-dimensional electrophoresis study of in vitro pellicle formation and dental caries susceptibility. Eur J Oral Sci 2006;114:147-153.

Walton RS, Brand DD, Czernuszka JT: Influence of telopeptides, fibrils and crosslinking on physicochemical properties of type I collagen films. J Mater Sci Mater Med 2010;21:451461.

Wang Q, Jia P, Cuenco KT, Feingold E, Marazita ML, Wang L, Zhao Z: Multi-dimensional prioritization of dental caries candidate genes and its enriched dense network modules. PLoS One 2013;8:e76666.

-Yamakoshi Y, Hu JC, Iwata T, Kobayashi K, Fukae M, Simmer JP: Dentin sialophosphoprotein is processed by MMP-2 and MMP-20 in vitro and in vivo. J Biol Chem 2006;281: 38235-38243.

Zehnder M, Wegehaupt FJ, Attin T: A first study on the usefulness of matrix metalloproteinase 9 from dentinal fluid to indicate pulp inflammation. J Endod 2011;37:17-20. 